Article

\title{
Evaluation of Corporate Websites and Their Influence on the Performance of Olive Oil Companies
}

\author{
Enrique Bernal Jurado ${ }^{1}$, Adoración Mozas Moral ${ }^{2}$, Miguel Jesús Medina Viruel ${ }^{3, *}$ and \\ Domingo Fernández Uclés 4 (1) \\ 1 Department of Economics, Campus Lagunillas, Building D-3, Office 266, University of Jaen, 23071 Jaen, \\ Spain; ebernal@ujaen.es \\ 2 Department of Business Organization, Marketing and Sociology, Campus Lagunillas, Building D-3, \\ Office 146, University of Jaen, 23071 Jaen, Spain; amozas@ujaen.es \\ 3 Department of Statistics, Econometrics, Operational Research, Business Organization and Applied \\ Economics, Puerta nueva, s/n, Applied Economics Office, University of Cordoba, 14071 Cordoba, Spain \\ 4 Department of Business Organization, Marketing and Sociology, Campus Lagunillas, Building D-3, \\ Office 107, University of Jaen, 23071 Jaen, Spain; dfucles@ujaen.es \\ * Correspondence: mjmedina@uco.es; Tel.: +34-675-218-477
}

Received: 24 February 2018; Accepted: 16 April 2018; Published: 20 April 2018

\begin{abstract}
Spain is among the largest producers of organic olive in the world. Yet the Spanish organic olive oil sector faces a major commercial problem due to an internal demand that is too small to match the volume of supply. Factors that explain this problem include the scarcity and scattered nature of points of sale, the lack of information available to consumers, and the very large gulf in the price between organic and nonorganic olive oil. To address these problems, the literature highlights the key commercial role of information and communication technologies (ICTs). The corporate website is a core element around which the company's e-commerce activity revolves. The goal of this study is to confirm the relationship between business efficiency, measured using data envelopment analysis (DEA), and the quality of the corporate website, measured using the extended Model of Internet Commerce Adoption (eMICA). Although this analysis did not identify a direct relationship between these two variables, fuzzy-set Qualitative Comparative Analysis (fsQCA) revealed that combinations of elements related to corporate website quality (interactivity and processing), organizational, and structural factors (size of firm and outsourcing of ICT management) can have a direct effect on organizational performance, measured in terms of economic efficiency.
\end{abstract}

Keywords: website; olive oil; Data Envelopment Analysis (DEA); extended Model of Internet Commerce Adoption (eMICA); fuzzy-set Qualitative Comparative Analysis (fsQCA)

\section{Introduction}

The steady advance and spread of technology throughout society in recent decades has increased the number and range of commercial operations that are conducted over the Internet. For example, between 2008 and 2015, the percentage of firms that sold their products or services via e-commerce rose by seven percentage points across the $28 \mathrm{EU}$ member states. During this period, one in five firms in the EU sold their products or services online [1]. Similarly, the use of social media and associated tools rose considerably, enabling and promoting online commercial transactions. In 2015, nearly 39\% of EU firms used social media (socials networks, blogs, wikis, etc.), especially to enhance their image and the image of their products and services [2].

The website is an essential tool for a firm to establish a strong online presence because it combines informative, relational, and transactional functionalities with online commercial transactions [3]. 
The Internet has shifted toward a more active and collaborative community, rendering static websites obsolete. Internet users participate by offering their opinions and experiences and by publishing, sharing, and adding information from other websites. Therefore, interactive services and platforms that enable communication and the exchange of information with the people that use these media are necessary. Firms have progressively adopted not only these dynamic web services and applications, but also new behaviors [2].

ICTs are a key element for the development of growing sectors, including organic agri-foods such as organic olive oil, of which Spain is one of the world's largest producers [4,5]. The importance of ICTs owes to the difficulties in commercializing such products, especially in terms of sales to the internal market. Heightened competition and the barriers faced by consumers when purchasing organic food (price, lack of information, and poor access to supply) make new technologies an important medium to improve organizational performance and, consequently, achieve competitive advantages.

Based on this rationale, the goal of this study is two-fold. First, the study examines whether there is evidence of a relationship between the economic efficiency of organic food companies with websites and the quality of these websites. Second, the study identifies the variables (structural, organizational, etc.) that enhance this relationship.

To achieve these goals, we proceed as follows: Following this introduction, we establish the theoretical framework that supports this study and formulate our hypotheses based on the literature review. In the method section, we describe the techniques that we used in this study-namely, Data Envelopment Analysis (DEA), the extended Model of Internet Commerce Adoption (eMICA), and fuzzy-set Quality Comparative Analysis (fsQCA). In the penultimate section, we present the results of the analysis. Finally, we draw conclusions from the study.

\section{Contextual Framework and Working Hypothesis}

According to the empirical evidence, ICTs, in general, and the Internet, in particular, have a positive effect on the economic development of organizations [6]. One of the tools offered by the Internet, the corporate website, is a core element around which the company's e-commerce activity revolves. In a sense, all implementations of e-marketing center on the corporate website, where users can find the majority of the information they need to make decisions regarding the purchase of the company's products. Therefore, an attractive design and interesting contents offer a source of competitive advantage for the organization. In the online environment, the website is the medium through which many potential customers are introduced to the company. As such, the website is the first reference that these customers have to form an impression of the company [7-9]. The website is also a place where existing customers can familiarize themselves with the company, providing an opportunity for these customers to interact with the company and gain further information in addition to the information they might have acquired through traditional channels. For example, such information might relate to the company's origin, location, or production methods [10]. The user's decision to make a purchase may depend on this website's capacity to positively influence the user's impression of the company [11]. This purchase is conditioned by the potential of the available information to compensate for the absence of personal contact and to generate sufficient trust between the company and its customers [12].

Scholars have shown that these technologies contribute to performance in terms of better productivity, profitability, process development, market value, and sustainability [13-17]. To achieve these results, however, companies must adopt and integrate the tools that the Internet has to offer by following a carefully planned strategy [18]. In addition to using these technologies, organizations must understand this medium and must devote the necessary efforts to managing these tools in an efficient manner [19]. Simply using ICTs to seek quick, basic solutions is a common mistake that fails to guarantee a positive outcome [20]. Innovation and technology adoption require commitment by the organization. Allocation of sufficient resources, efficient management by the right people, and control of technology diffusion are all necessary [21]. Thus, it is important to consider technological and social 
variables that are inherent in the implementation of innovations and that, together with the concerted support and effort of the entire organization, lead to the successful adoption of technology [4,6,22,23]. We, therefore, formulate the following hypothesis:

Hypothesis 1 (H1): Having a high-quality corporate website alone does not positively affect business efficiency.

Combining a corporate website with the active use of online social networks facilitates contact, the exchange of information, and interactions with consumers, thereby influencing their purchase decisions [23-26]. These effects arise because not only are these platforms capable of providing high-quality information to consumers, they also leverage user feedback to expand and improve, which is a key factor for achieving customer loyalty [27]. Accordingly, scholars have reported that these tools are capable of generating considerable economic value [28]. Specifically, the use of social networks can increase the organization's productivity $[29,30]$ and prestige, potentially creating competitive advantages [31]. We, therefore, formulate the following hypothesis:

Hypothesis 2 (H2): The presence of tools that stimulate interaction between the company and users enhances the positive effect of the website on business efficiency.

E-commerce allows organizations to access a much larger market because the Internet reduces the importance of the physical distances that separate supply and demand [32]. In fact, ICTs are particularly useful for internationalization [33] because they facilitate negotiations and the exchange of information with consumers in the international market, which yields multiple benefits $[34,35]$. These benefits include [36] facilitating access to global markets, creating openings for internationalization, improving procurement negotiations, and increasing organizational efficiency.

E-commerce thus allows organizations to grasp major commercial opportunities cheaply, thereby becoming synonymous with greater productivity and efficiency [37]. Such advantages are especially useful in a sector, such as the olive oil sector, which relies heavily on exports and has encountered serious commercial problems [5]. We, therefore, formulate the following hypothesis:

Hypothesis 3 (H3): The use of an online store to enable online transactions enhances the positive effect of the corporate website on business efficiency.

The literature has confirmed the existence of a positive relationship between the size of the firm and economic efficiency $[38,39]$. Numerous theories, including the theory of economies of scale and the theory of economies of scope, support the assertion that larger businesses have greater process efficiency and more efficient operational functions [40]. In the online environment, the positive network externalities that are generated by ICTs make these platforms more attractive as the number of users increases [19]. Thus, because of the greater volume of information shared among users, the value and utility of a social network increases as the number of users with links to the organization grows [41]. We, therefore, formulate the following hypothesis:

Hypothesis 4 (H4): Larger organizational size makes the corporate website more likely to exert a positive effect on business efficiency.

Assimilating and internally managing innovations is fundamental for organizations to develop and achieve competitive advantages [42]. For example, a community manager helps companies efficiently use and establish a strong social media presence [43]. Similarly, a group of professionals who are well trained and committed to managing different online applications enables the adoption and leveraging of these applications [21]. If internal staff lack this training, it may be recommendable to outsource the management of these technologies [44]. This situation is applicable to the olive oil sector, where the scarcity of human resources devoted to ICT management and poor ICT training have 
been highlighted as some of the sector's primary weaknesses [45]. These weaknesses can be corrected through outsourcing, which delegates these functions to specialized professionals. We, therefore, formulate the following hypothesis:

Hypothesis 5 (H5): In organizations that lack internal specialists to manage ICT tools, the positive effect of the corporate website on business efficiency can be obtained through outsourcing.

\section{Materials and Methods}

The target population in this study comprised producers and vendors of organic olive oil that are registered in the Andalusian Information System for Organic Production (SIPEA). Andalusia is the region with the highest production in Spain. The number of companies registered in the system is 188. We contacted the CEO of each firm to conduct a telephone questionnaire. We received valid questionnaires from 147 companies. We, therefore, had a sampling error of $3.8 \%$ for a confidence interval of $95 \%$. In this study, we focused exclusively on organizations that had their own websites, reducing the sample size to 109 companies. To pursue our research goals, we used the following methods:

\subsection{Data Envelopment Analysis (DEA)}

We first evaluated organizational efficiency in economic terms. To do so, we used DEA, which performs better than traditional analyses that are based on simply calculating profitability indicators. DEA outperforms traditional methods because it facilitates multidimensional processing of the principal expense items (or inputs) with respect to the income (or outputs) in a systematic, comparative manner, enabling the identification of organizational best practices in terms of performance, productivity, and efficiency [46,47]. We used the classic output-oriented CCR (Charnes, Cooper, and Rhodes) and BCC (Banker, Charnes, and Cooper) models. The latter includes the returns to scale variable [48]. Maximization of outputs is considered the most fruitful approach given the key commercial issue facing these companies and the fact that the inputs are subject to alternate bearing. In this model, the output was sales revenue, and the inputs were expenditure on materials and raw materials, personnel expenses, and depreciation of tangible fixed assets [30]. One of the primary weaknesses of this method is its high sensitivity to outliers [49]. To resolve this issue, we used the super-efficiency technique [50], pre-selecting a screen of 2 to eliminate any cases with efficiency scores that were higher than this screen. Two companies were eliminated from the sample following this procedure.

\subsection{Extended Model of Internet Commerce Adoption (eMICA)}

To analyze website quality, we used the eMICA technique [51], which is based on the work of Burgess and Cooper $[52,53]$. In recent years, the eMICA has been one of the most widely used models to analyze the adoption of ICTs and e-commerce across a range of sectors [54-59].

This model, which consists of three stages, classifies websites according to their maturity. The first stage is web-based promotion (information). This stage consists of collecting and analyzing the information that the company publishes on its website. This stage is divided into two layers: layer 1 (basic information) and layer 2 (rich information). The second stage relates to the provision of information and services and interactivity (dynamic information). In this stage, the degree of interaction between the firm and the users of the website is analyzed. This stage has three layers: layer 1 (low-level interactivity), layer 2 (medium interactivity), and layer 3 (high interactivity). Finally, the third stage, processing, evaluates the quality of the transactions that are processed on the website. Each layer consists of items that take the value 1 (indicating presence) or 0 (indicating absence). To obtain the indicators for this procedure, we drew on a prior study [59] of the olive oil sector of a Spanish region (Table 1). 
Table 1. Items used for eMICA analysis of websites.

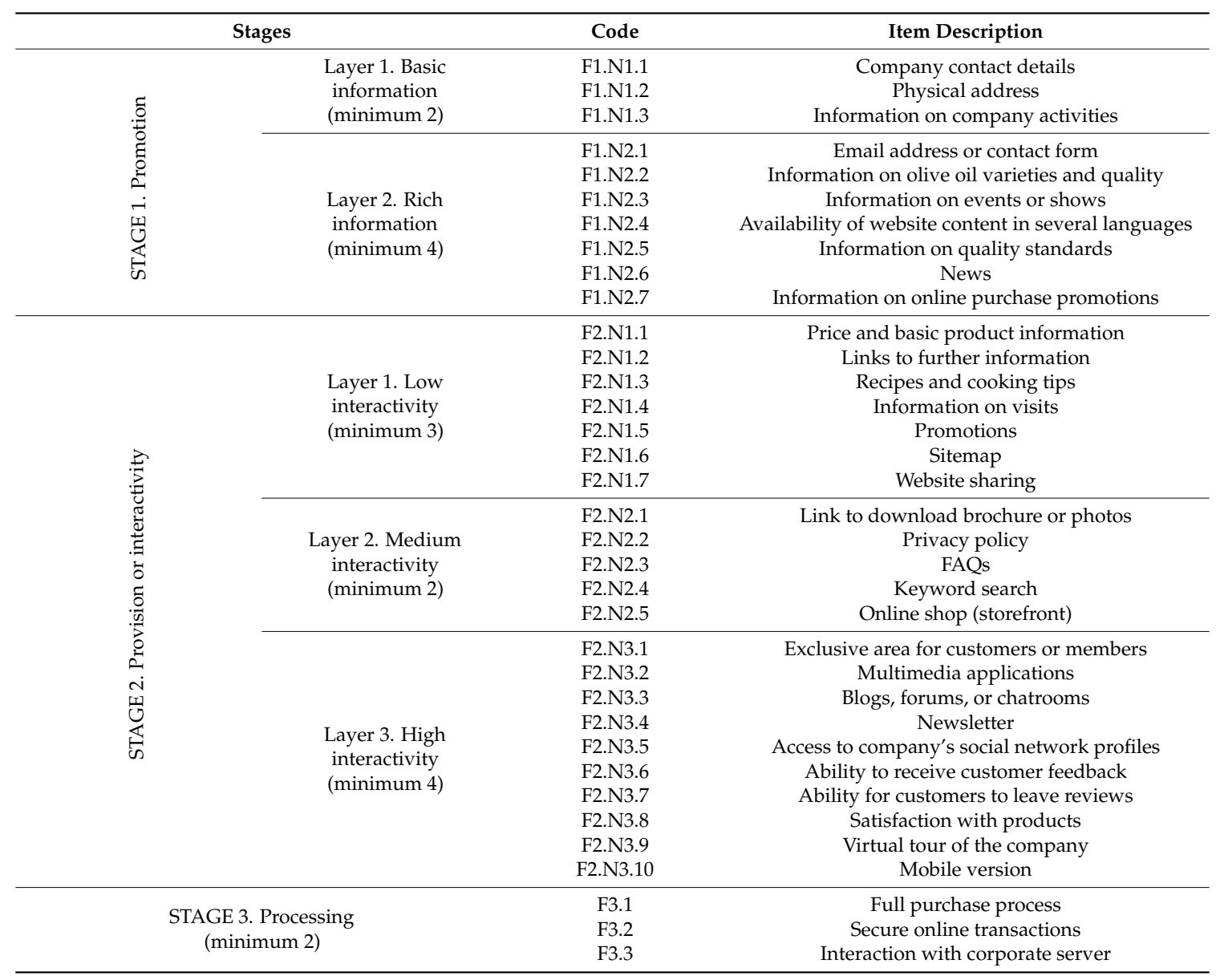

Source: adapted by the authors [51,59].

In the eMICA, starting with layer 1 of stage 1 , each website is assigned a certain level if it meets a minimum number of criteria (items), which are shown in Table 1. For example, if a website has two of the three items that belong to layer 1 of stage 1 , it is considered a layer 1 website. It is then assessed for the next layer, and so forth. Thus, each website was evaluated for each layer, provided it met the requirements for the previous layer. In eMICA analysis, this form of evaluation is called layer-by-layer analysis. The primary reason is to overcome one of the principal weaknesses of the eMICA-that a website can simultaneously be in two layers [60].

To evaluate the existence of the relationship between variables (i.e., general economic efficiency, using the DEA, and the quality of the website, using the eMICA), we compared the conditional distributions of these variables using statistical tests based on Kendall's tau coefficient. This was the most suitable approach given the nature of the variables in this study. We also used Kendall's tau coefficient to identify significant relationships between the efficiency and the sum of all items used in the eMICA and between the efficiency and the sum of items in each stage (information, interactivity, and processing). The overall sum and the sum for each stage were calculated using a value of 1 to indicate the presence of each item and 0 to indicate its absence.

\subsection{Fuzzy-Set Quality Comparative Analysis (fs $Q C A$ )}

The final phase of our analysis consisted of fuzzy-set Qualitative Comparative Analysis (fsQCA). This method was used only if necessary-that is, if the previous phase of analysis failed to identify a direct relationship between the quality of the website and business performance [61]. The goal of the fsQCA was to observe whether the overall website quality and the quality for each stage of the 
eMICA (measured as the sum of all items in the eMICA or all items from each stage of the eMICA, respectively), when combined with other factors, explain high levels of efficiency. The methodological advantage of fsQCA, with respect to conventional csQCA, is that fsQCA enables the use of continuous and interval variables, as well as dichotomous variables [62]. These variables must be calibrated before they may be included in the model. Calibration assigns values between 0 and 1 depending on the degree of membership within the category $[63,64]$. These variables are called fuzzy variables. To conduct this analysis, we used fsQCA 2.5 software (Irvine, CA, USA). The model employed the BCC_O efficiency index as the outcome (already calibrated between 0 and 1) and the variables in Table 2 as antecedents or causal conditions.

Table 2. Antecedents in the fsQCA model.

\begin{tabular}{ccc}
\hline Variable & & Type \\
\hline Active use of online social networks & Usa_rsv & Dichotomous variable \\
Internal management of ICTs & Gestión_TIC & Dichotomous variable \\
Total number of company employees & Empleados & Fuzzy variable \\
Sum of items from the eMICA & Emica & Fuzzy variable \\
Website information (sum of items from stage 1) & Inf.eMICA & Fuzzy variable \\
Website interactivity (sum of items from stage 2) & Int.eMICA & Fuzzy variable \\
Website processing (sum of items from stage 3) & Pro.eMICA & Fuzzy variable \\
\hline
\end{tabular}

Source: compiled by the authors.

\section{Results and Discussion}

\subsection{Analysis of Economic Efficiency}

We first analyzed the general economic efficiency of organic olive oil companies with websites. To do so, we considered the primary expense and income items of these companies, as described earlier. The results of this initial analysis appear in Table 3.

Table 3. DEA results for general economic efficiency.

\begin{tabular}{ccc}
\hline & CCR_O & BCC_O \\
\hline Number of efficient decision-making units & 10 & 15 \\
Percentage of efficient decision-making units & $9.17 \%$ & $13.76 \%$ \\
Average DEA score & $50.86 \%$ & $58.61 \%$ \\
Standard deviation of the scores & 0.2394 & 0.2417 \\
\hline
\end{tabular}

Source: compiled by the authors.

Table 3 shows the efficiency scores provided by the DEA, employing the classic output-oriented CCR and BCC models. The results for the BCC model show the variations in efficiency after considering the scale efficiency [65]. The number of fully-efficient organizations was small-approximately $9 \%$ and $14 \%$ of the sample for the CCR and BCC models, respectively. On average, technical efficiency was $50.86 \%$ for the CCR model and $58.61 \%$ for the BCC model.

These efficiency rates are similar to those reported in other studies of this sector $[5,66]$. The efficiency scores in Table 3 reveal a substantial gulf between fully-efficient organizations and all other organizations. This finding highlights the importance of innovation and sustainable development as measures to improve performance and thereby achieve greater efficiency $[15,32,67]$.

\subsection{Analysis of Corporate Website Quality}

We also analyzed the quality of the website using the eMICA method. Table 4 shows the low adoption of e-commerce within the sector. More than half (56.88\%) of companies did not pass the second stage. Furthermore, few companies achieved the highest standard of quality available in the model. Only $7.34 \%$ of companies passed the third stage. 
Table 4. eMICA results for the analysis of website quality.

\begin{tabular}{|c|c|c|c|c|c|}
\hline Stage & Companies & Percentage & Layer & Companies & Percentage \\
\hline \multirow{2}{*}{ Stage 1} & \multirow{2}{*}{62} & \multirow{2}{*}{56.88} & Layer 1. Stage 1 & 26 & 23.85 \\
\hline & & & Layer 2. Stage 1 & 36 & 33.03 \\
\hline \multirow{3}{*}{ Stage } & \multirow{3}{*}{39} & \multirow{3}{*}{35.78} & Layer 1. Stage 2 & 3 & 2.75 \\
\hline & & & Layer 2. Stage 2 & 34 & 31.19 \\
\hline & & & Layer 3 . Stage 2 & 2 & 1.83 \\
\hline Stage 3 & 8 & 7.34 & Layer 1 . Stage 3 & 8 & 7.34 \\
\hline TOTAL & 109 & 100.00 & TOTAL & 109 & 100.00 \\
\hline
\end{tabular}

\subsection{Analysis of the Relationship between Economic Efficiency and Corporate Website Quality}

We used Kendall's tau correlation coefficient to analyze the strength of the association between corporate website quality (measured using the eMICA) and general economic efficiency (measured using the DEA, BCC model). The value of this coefficient in each case was as follows: for the eMICA, $\tau=0.05$; for the sum of items in the eMICA, $\tau=0.026$; for the sum of items from stage 1 (information), $\tau=0.048$; for the sum of items from stage 2 (interactivity), $\tau=0.011$; and for the sum of items from stage 3 (processing), $\tau=0.018$. None of these values was statistically significant. These values, therefore, indicate the lack of a clear relationship between these variables, thereby confirming Hypothesis 1.

Simply having a corporate website, even if this website is of a high quality, is not enough to guarantee improved organizational performance in terms of economic efficiency. Other studies have reported that the efficiency in the use of other social media technologies is related to different organizational characteristics [4]. To improve business performance in terms of economic efficiency, companies must combine the use of technology with other organizational elements that enhance the impact of this technology on the company $[5,45,66]$.

To investigate this relationship further, we studied whether combining a high-quality website with other organizational, structural, and ICT use characteristics exerts a positive effect on the efficiency of the company. To do so, we applied fsQCA using fsQCA 2.5 software. The results of this analysis appear in Table 5, which displays six combinations of causal conditions that are sufficient to explain a company's high economic efficiency.

Table 5. Results of fsQCA.

\begin{tabular}{lccc}
\hline \multicolumn{1}{c}{ Causal Configuration } & Raw Coverage & Unique Coverage & Consistency \\
\hline usa_rsv*empleados & 0.379476 & 0.079833 & 0.854450 \\
pro.emica* $\sim$ gestion_tic*int.emica $^{*}$ & 0.295458 & 0.051930 & 0.801177 \\
$\sim$ usa_rsv* ${ }^{*}$ estion_tic* $\sim$ int.emica & 0.277786 & 0.123237 & 0.758358 \\
$\sim$ pro.emica*empleados & 0.201829 & 0.030383 & 0.859974 \\
pro.emica* $\sim$ usa_rsv* $\sim$ empleados*int.emica & 0.110526 & 0.035033 & 0.900253 \\
pro.emica*usa_rsv*gestión_tic* $\sim$ int.emica & 0.078902 & 0.020152 & 0.796557 \\
\hline Solution coverage: & & 0.814292 & \\
Solution consistency: & & 0.778107 & \\
\hline
\end{tabular}

Source: compiled by the authors.

The first two causal combinations in Table 5 have the highest raw coverage. These combinations reflect a direct relationship between economic efficiency and combinations of conditions such as: (a) the active use of online social networks and number of employees, thereby confirming Hypotheses 2 and 4; and (b) a high quality of processing on the website (online commercial transactions) and a high degree of interactivity on the website, thereby confirming Hypotheses 2 and 3. Combination (b) reveals an inverse relationship between efficiency and internal ICT management, indicating greater efficiency 
in firms that outsource ICT management to specialists, thereby confirming hypothesis 5 . The small number of employees and their scant training $[5,30,67]$ potentially explains this relationship. To reap the rewards of ICTs, companies must have certain structural and organizational attributes that firms in the olive oil sector lack $[59,68]$.

The combination of an active use of online social networks and the number of employees explains almost $38 \%$ of the efficiency of the company. The combination of high-quality processing on the website (online commercial transactions), outsourcing of ICT management, and a high degree of interactivity on the website explains almost $30 \%$ of efficiency. The solution for this model is a complex solution. The set of sufficient causal configurations that we identified using fsQCA have a coverage score of 0.814292 , so these combinations together explain $81.43 \%$ of the outcome of the model. The consistency score is 0.778107 . The results of the fsQCA lead to the acceptance of our hypotheses.

Finally, the analysis of necessary conditions shows that all variables or causal conditions failed to attain the minimum consistency score of 0.9 recommended in the literature [61]. Therefore, no single condition guarantees the general economic efficiency of the firm. In short, the results support the idea that the organization's commitment to ICTs contributes to better organizational performance and efficient operations $[30,66]$.

\section{Conclusions}

The purpose of this study was two-fold. First, we analyzed whether the economic efficiency of organic olive oil companies is related to the quality of their corporate websites. Second, we identified the variables (structural, organizational, etc.) that enhance this relationship. The results reveal the absence of a direct relationship between these variables. This finding implies that simply adopting a corporate website, regardless of whether it is of a high quality, does not always lead to better organizational performance in terms of economic efficiency.

In light of this finding, we conducted fsQCA to reveal the causal combinations that explain this relationship. These configurations consist of factors that determine website quality and factors associated with organizational and structural characteristics. The factors that determine website quality include good processing capabilities (complete and secure online transactions), high interactivity (blog, exclusive area for customers, forums, mobile version, etc.), and the availability of links to online social networks. The organizational and structural factors include the size of the company and the outsourcing of ICT management. The two primary causal configurations indicate that certain combinations of these factors positively relate to business performance, measured in terms of economic efficiency. This finding suggests that the quality and quantity of the information available on the website play a secondary role, whereas the ability of the website to communicate with users, allow users to complete transactions, and share information with customers plays a primary role.

The analysis also reveals the decisive role of the organizational and structural factors of the firm in enabling the firm to capitalize on the advantages of commercializing its products online. Combining the aforementioned elements of interactivity with a higher number of employees or the outsourcing of ICT management helps the firm obtain the maximum benefit from these tools. This finding provides new arguments to many scholars and professionals, who, for several decades, have advocated the need for policies of integration and concentration in the Spanish olive oil sector and for a commitment to the professionalization of management within the sector. This finding should encourage public and private organizations to take timely measures and correct the gap with respect to other sectors of the economy. ICTs are essential to improve the competitiveness and development of the olive sector and to a means of sustaining rural livelihoods.

It is also important to highlight the principal limitations of this study. First, this study was primarily aimed at companies in the organic olive oil sector. However, we believe that our conclusions may be extrapolated to much of the organic agri-food sector, which generally faces similar commercialization problems. Second, we focused on the Spanish market. Although Spain is a major producer of olive oil, it would be of interest to compare our findings with findings for other countries 
that produce olive oil. Third, the purchase behavior of consumers of organic products is characterized by a prominent awareness of organic food. In light of the lack of information and confusion regarding the organic agri-food market, future studies should compare whether the exchange of information via social networks plays a more prominent role in the purchase of organic products than in the purchase of conventional products.

Acknowledgments: No external funding was received for this study.

Author Contributions: The authors contributed equally to this work.

Conflicts of Interest: The authors declare no conflict of interest.

\section{References}

1. Eurostat. Community Survey on ICT Usage in Enterprises. 2016. Available online: http://ec.europa.eu/ eurostat/statistics-explained/index.php/Glossary:Community_survey_on_ICT_usage_in_enterprises (accessed on 5 February 2017).

2. Eurostat. ICT Usage and E-Commerce in Enterprises. 2016. Available online: http://ec.europa.eu/ eurostat/statistics-explained/index.php/Social_media_-_statistics_on_the_use_by_enterprisesenterprises (accessed on 10 March 2017).

3. Meroño, Á.L.; Arcas, N. Equipamiento y gestión de las tecnologías de la información en las cooperativas agroalimentarias. Revista de Economía Pública Social y Cooperativa 2006, 54, 5-30.

4. Mozas, A.; Bernal, E.; Medina, M.J.; Fernández, D. Factors for success in online social networks: An fsQCA approach. J. Bus. Res. 2016, 69, 5261-5264. [CrossRef]

5. Medina, M.J.; Bernal, E.; Mozas, A.; Moral, E.; Fernández, D. Efficiency of organic farming companies that operate in an online environment. Custos e Agronegocio 2016, 11, 264-289.

6. Becchetti, L.; Andres, D.; Paganetto, L. ICT investment, productivity and efficiency: Evidence at firm level using a stochastic frontier approach. J. Product. Anal. 2003, 20, 143-167. [CrossRef]

7. Winter, S.; Saunders, C.; Hart, P. Electronic window dressing: Impression management with websites. Eur. J. Inf. Syst. 2003, 12, 309-322. [CrossRef]

8. Zhang, P.; Dran, G.M. User expectations and rankings of quality factors in different web site domain. Int. J. Electron. Commer. 2002, 6, 9-33.

9. Chen, S.; Macredie, R. The assessment of usability of electronic shopping. A heuristic evaluation. Int. J. Inf. Manag. 2005, 25, 516-532. [CrossRef]

10. Yang, Z.; Cai, S.; Zhou, Z.; Zhou, N. Development and validation of an instrument to measure user perceived service quality of information presenting web portals. Inf. Manag. 2005, 42, 575-589. [CrossRef]

11. Van Der Heijden, H.; Verhagen, T.; Creemers, M. Understanding online purchase intentions: Contributions from technology and trust perspectives. Eur. J. Inf. Syst. 2004, 12, 41-48. [CrossRef]

12. Mckinney, V.; Yoon, K.; Zahedi, F.M. The measurement of web-customer satisfaction: An expectation and disconfirmation approach. Inf. Syst. Res. 2002, 13, 296-315. [CrossRef]

13. Dedrick, J.; Gurbaxani, V.; Kraemer, K.L. Information technology and economic performance: A critical review of the empirical evidence. ACM Comput. Surv. 2003, 35, 1-28. [CrossRef]

14. Bayo-Moriones, A.; Lera-López, F. A firm-level analysis of determinants of ICT adoption in Spain. Technovation 2007, 27, 352-366. [CrossRef]

15. Can, U.; Alatas, B. Big Social Network Data and Sustainable Economic Development. Sustainability 2017, 9, 2027. [CrossRef]

16. Al Wakil, A. When Gambling is Not Winning: Exploring Optimality of VIX Trading under the Expected Utility Theory. J. Bus. Account. Financ. Perspect. 2018, in press.

17. Cuomo, M.T.; Tortora, D.; Mazzucchelli, A.; Festa, G.; Di Gregorio, A.; Metallo, G. Impacts of Code of ethics on financial performance in the Italian listed companies of bank sector. J. Bus. Account. Financ. Perspect. 2018, in press.

18. Li, C.; Bernoff, J. Groundswell; Harvard Business School Publishing: Boston, MA, USA, 2011.

19. Kaplan, A.M.; Haenlein, M. Users of the world, unite! The challenges and opportunities of Social Media. Bus. Horiz. 2010, 53, 59-68. [CrossRef]

20. Godin, S. Meatball Sundae: Is Your Marketing Out of Sync? Penguin Books Ltd.: London, UK, 2007. 
21. Peansupap, V; Walker, D. Information communication technology (ICT) implementation constraints: A construction industry perspective. Eng. Constr. Archit. Manag. 2006, 13, 364-379. [CrossRef]

22. Rogers, E.M. Diffusion of Innovations; Simon and Schuster: New York, NY, USA, 2010.

23. Sabatino, M. Competitiveness and resilience of the productive districts in Sicily. The behavior of the Sicilian production areas during the economic crisis. Contemp. Econ. 2016, 10, 233-248. [CrossRef]

24. Redmond, E.C.; Griffith, C.J. Assessment of consumer food safety education provided by local authorities in the UK. Br. Food J. 2006, 108, 732-752. [CrossRef]

25. Tian, Y.; Robinson, J.D. Media use and health information seeking: An empirical test of complementarity theory. Health Commun. 2008, 23, 184-190. [CrossRef] [PubMed]

26. Kuttschreuter, M.; Rutsaert, P.; Hilverda, F.; Regan, Á.; Barnett, J.; Verbeke, W. Seeking information about food-related risks: The contribution of social media. Food Qual. Preference 2014, 37, 10-18. [CrossRef]

27. Mago, B.; Trivedi, P. Evidence of customers' perceptions toward the usage of social networking sites as E-business mechanism in UAE. Eur. Sci. J. 2014, 10, 1-15.

28. Stephen, A.T.; Toubia, O. Deriving value from social commerce networks. J. Mark. Res. 2010, 47, $215-228$. [CrossRef]

29. Karoui, M.; Dudezert, A.; Leidner, D.E. Strategies and symbolism in the adoption of organizational social networking systems. J. Strateg. Inf. Syst. 2015, 24, 15-32. [CrossRef]

30. Bernal, E.; Mozas, A.; Fernández, D.; Medina, M.J. Explanatory factors for efficiency in the use of social networking sites. The case of organic food products. Psychol. Mark. 2017, 34, 1119-1126.

31. Durkin, M.; Mcgowan, P.; Mckeown, N. Exploring social media adoption in small to medium-sized enterprises in Ireland. J. Small Bus. Enterp. Dev. 2013, 20, 716-734. [CrossRef]

32. Dholakia, R.; Kshetri, N. Factors impacting the adoption of the Internet among SMEs. Small Bus. Econ. 2004, 23, 311-322. [CrossRef]

33. Castellani, D.; Zanferi, A. Internationalization, innovation and productivity: How do firms differ in Italy? World Econ. 2007, 30, 156-176. [CrossRef]

34. Zhuang, Y.; Lederer, A.L. An instrument for measuring the business benefits of E-commerce retailing. Int. J. Electron. Commer. 2003, 7, 65-99.

35. Srivastava, S.; BarNir, A. Customer-firm interaction and the small firm: Exploring individual, firm, and environmental level antecedents. J. Small Bus. Strateg. 2016, 26, 23-50.

36. Goldstein, A.; O'Connor, D. E-Commerce for Development: Prospects and Policy Issues; OECD Development Centre Mimeo: Paris, France, 2000.

37. Baourakis, G.; Kourggiantakis, M.; Migdalas, A. The impact of e-commerce on agro-food marketing. The case of agricultural cooperatives, firms and consumers in Crete. Br. Food J. 2002, 104, 580-590. [CrossRef]

38. Gooding, R.Z.; Wagner, J.A., III. A meta-analytic review of the relationship between size and performance: The productivity and efficiency of organizations and their subunits. Adm. Sci. Q. 1985, 30, 462-481. [CrossRef]

39. Voulgaris, F.; Lemonakis, C. Productivity and efficiency in the agri-food production industry: The case of fisheries in Greece. Procedia Technol. 2013, 8, 503-507. [CrossRef]

40. Schneider, G.P. Comercio Electrónico; Thomson: Luton, UK, 2004.

41. Torrent, J. Knowledge products and network externalities: Implications for the business strategy. J. Knowl. Econ. 2015, 6, 138-156. [CrossRef]

42. Gray, C. Absorptive capacity, knowledge management and innovation in entrepreneurial small firms. Int. J. Entrep. Behav. Res. 2006, 12, 345-360. [CrossRef]

43. Ayerdi, K.; Galdospin, T.; Dasilva, J.A. The role of community manager in the marketing strategies of the Spanish companies most active on social networks. Estudios Sobre el Mensaje Periodístico 2014, 21, 385-402.

44. Abramovsky, L.; Griffith, R. Outsourcing and offshoring of business services: How important is ICT? J. Eur. Econ. Assoc. 2006, 4, 594-601. [CrossRef]

45. Fernández, D.; Mozas, A.; Bernal, E.; Medina, M.J. Uso y eficiencia de la social media. Un análisis desde la economía social. CIRIEC-España. Revista De Economía Pública Social y Cooperativa 2016, 88, 5-27.

46. Cook, W.D.; Tone, K.; Zhu, J. Data envelopment analysis: Prior to choosing a model. Omega 2014, 44, 1-4. [CrossRef]

47. Zhu, J. DEA Based Benchmarking Models. In Data Envelopment Analysis; Springer: Boston, MA, USA, 2015; pp. 291-308. 
48. Charnes, A.; Cooper, W.W.; Lewin, A.Y.; Seiford, L.M. (Eds.) Data Envelopment Analysis: Theory, Methodology, and Applications; Springer Science \& Business Media: Berlin, Germany, 2013.

49. De Witte, K.; Marques, R. Influential observations in frontier models, a robust non-oriented approach to the water sector. Ann. Oper. Res. 2010, 181, 377-392. [CrossRef]

50. Banker, R.D.; Gifford, J.L. A Relative Efficiency Model for the Evaluation of Public Health Nurse Productivity; Carnegie Mellon University: Pittsburgh, PA, USA, 1988.

51. Burgess, L.; Parish, B.; Alcock, C. To what extent are regional tourism organisations (RTOs) in Australia leveraging the benefits of web technology for destination marketing and eCommerce? Electron. Commer. Res. 2011, 11, 341-355. [CrossRef]

52. Burgess, L.; Cooper, J. The Status of Internet Commerce in the Manufacturing Industry in Australia: A survey of Metal Fabrication Industries. In Proceedings of the Second Collecter Conference on Electronic Commerce, Sydney, Australia, 29 September 1998.

53. Burgess, L.; Cooper, J. Extending the viability of MICA (Model of Internet Commerce Adoption) as a metric for explaining the process of business adoption of Internet commerce. In Proceedings of the International Conference on Telecommunications and Electronic Commerce, Dallas, TX, USA, 16-19 November 2000.

54. Sepúlveda, D.; Sepúlveda, D.; Pérez, F.; Figueroa, E. Propuesta de modelo para Adopción del Comercio Electrónico en empresas del Sector Agroindustrial en México. In Investigación en Matemáticas, Economía y Ciencias Sociales; Austral University of Chile (UACh): Valdivia, Chile, 2014; pp. 424-437.

55. Doolin, B.; Burgess, L.; Cooper, J. Evaluating the use of the Web for tourism marketing: A case study from New Zealand. Tour. Manag. 2002, 23, 557-561. [CrossRef]

56. Ting, P.H.; Wang, S.T.; Bau, D.Y.; Chiang, M.L. Website evaluation of the top 100 hotels using advanced content analysis and eMICA model. Cornell Hosp. Q. 2013, 54, 284-293. [CrossRef]

57. Platania, M. Agritourism farms and the web. An exploratory evaluation of their websites. Econ. Inform. 2014, $6,51-58$.

58. Sepúlveda, D.; Sepúlveda, D.; Pérez, F. Diagnóstico, Retos del Comercio Electrónico en el Sector Agroindustrial Mexicano; ECORFAN: México City, Mexico, 2015.

59. Cristóbal, E.; Montegut, Y.; Daries, N. Cooperativismo 2.0: Presencia en Internet y desarrollo del comercio electrónico en las cooperativas oleícolas de Cataluña. Revista de Estudios Cooperativos 2017, 124, 47-73. [CrossRef]

60. Schmidt, S.; Serra, A.; Dos Santos, C.P. The characteristics of hotel websites and their implications for website effectiveness. Int. J. Hosp. Manag. 2008, 27, 504-516. [CrossRef]

61. Ragin, C.C. Redesigning Social Inquiry: Fuzzy Sets and Beyond; University of Chicago Press: Chicago, IL, USA, 2008.

62. Roig, N.; González, T.F.; Llopis-Martinez, J. An overview of qualitative comparative analysis: A bibliometric analysis. J. Innov. Knowl. 2017, 2, 15-23. [CrossRef]

63. Schneider, M.R.; Schulze-Bentrop, C.; Paunescu, M. Mapping the institutional capital of high-tech firms: A fuzzy-set analysis of capitalist variety and export performance. J. Int. Bus. Stud. 2010, 41, 246-266. [CrossRef]

64. Woodside, A.G. Moving beyond multiple regression analysis to algorithms: Calling for adoption of a paradigm shift from symmetric to asymmetric thinking in data analysis and crafting theory. J. Bus. Res. 2013, 66, 463-472. [CrossRef]

65. Solana, J.; Caravaca, M.; Para-González, L. Two-stage data envelopment analysis of Spanish regions: Efficiency determinants and stability analysis. Contemp. Econ. 2016, 10, 259-274. [CrossRef]

66. Bernal, E.; Mozas, A.; Fernández, D.; Medina, M.J. Determining Factors for Economic Efficiency in the Organic Olive Oil Sector. Sustainability 2017, 9, 784. [CrossRef]

67. Rekik, L.; Bergeron, F. Green Practice Motivators and Performance in SMES: A Qualitative Comparative Analysis. J. Small Bus. Strateg. 2017, 27, 1.

68. Fernández, D.; Bernal, E.; Mozas, A.; Medina, M.J.; Moral, E. El Sector Cooperativo Oleícola y el Uso de las TIC: Un Estudio Comparativo Respecto a Otras Formas Jurídicas. Revista de Estudios Cooperativos 2016, 120, $53-75$.

(C) 2018 by the authors. Licensee MDPI, Basel, Switzerland. This article is an open access article distributed under the terms and conditions of the Creative Commons Attribution (CC BY) license (http:/ / creativecommons.org/licenses/by/4.0/). 